\title{
Effect of Dietary Incorporation of Dried Fenugreek (Trigonella foenum- graceum) Leaf Powder on Growth Performance and Nutrient utilization in Commercial Broiler Chicken
}

\author{
Nandita, B. C. Mondal and Manju Lata* \\ Department of Animal Nutrition, College of Veterinary and Animal Sciences, G. B. Pant \\ University of Agriculture and Technology, Pantnagar, Uttarakhand, 263145, India \\ *Corresponding author
}

\section{Keywords}

Broiler chicks, Fenugreek, Growth performance, Nutrient utilization

Article Info

Accepted: 10 January 2021 Available Online: 10 February 2021

\section{A B S T R A C T}

A feeding trial was conducted to discern the effect of dietary incorporation of dried fenugreek (Trigonella foenum-graceum) leaf powder on growth performance and nutrient utilization in commercial broilers. A total of 120 , day-old commercial broiler chicks were divided randomly into four treatment groups with three replicates each i.e. 10 chicks per replicate. Chicks of treatment $T_{1}$ (control) were fed basal diet whereas in treatment group $\mathrm{T}_{2}, \mathrm{~T}_{3}$ and $\mathrm{T}_{4}$, the basal diet was supplemented with dried fenugreek leaf powder @ 0.5\%, 1\% and 1.5\%, respectively. The feeding trial lasted for 42 days viz., 0-21 days (starter phase) and 22-42 days (finisher phase). Feed intake and body weight changes in broiler chicks were recorded at weakly intervals and a metabolism trial of 4 days collection period was conducted during the $6^{\text {th }}$ week of feeding trial. In the starter phase, the body weight gain of broiler chicks of group $\mathrm{T}_{3}(685.20 \mathrm{~g})$ was significantly $(\mathrm{P}<0.05)$ higher than other groups i.e. $\mathrm{T}_{1}(636.40 \mathrm{~g}), \mathrm{T}_{2}(673.58 \mathrm{~g})$ and $\mathrm{T}_{4}(675.43$ g) where as in finisher phase, the body weight gain of broiler chicks fed diet supplemented with fenugreek leaf powder @ $1 \%$ i.e. $\mathrm{T}_{3}(1587.30 \mathrm{~g})$ and $1.5 \%$ i.e. $\mathrm{T}_{4}(1522.20 \mathrm{~g})$ was significantly higher in $\mathrm{T}_{2}(1489.70 \mathrm{~g})$ and control group $\mathrm{T}_{1}$ $(1477.60 \mathrm{~g})$. Feed conversion ratio and performance index were also improved in broiler chicks of groups $\mathrm{T}_{3}$ and $\mathrm{T}_{4}$. During whole experimental period (0-42 days), supplementation of fenugreek leaf powder improved broiler performance in terms of feed intake, body weight gain, feed conversion ratio and performance index. Final body weight was recorded as maximum in group fed diet supplementing with $1 \%$ fenugreek leaf powder $(2321.70 \mathrm{~g})$ followed by $\mathrm{T}_{4}(2246.70 \mathrm{~g}), \mathrm{T}_{2}$ $(2231.70 \mathrm{~g})$ and minimum in $\mathrm{T}_{1}(2162.80 \mathrm{~g})$. Nutrient utilization in terms of dry matter, crude protein and ether extract was significantly $(\mathrm{P}<0.05)$ improved in broilers fed diet supplemented with $1 \%$ fenugreek leaf powder $\left(\mathrm{T}_{3}\right)$. 


\section{Introduction}

Poultry industry is one of the industries to meet out the daily protein requirement of human population through the meat and egg. The fast growing nature of broilers and there short generation interval has been associated with use of antibiotic as feed additive in animal feed. However, the use of antibiotic in the diet is restricted because of their residual effect on birds and in turn adverse effect on human health, environmental hazards and development of antimicrobial resistant strains of microorganisms (Lee et al., 2004). Now a day's herbal products can act an alternative feed additive in poultry production sector as they have positive impact on improved feed conversion ratio and growth performance, under intense system of rearing and more widely accepted by consumers. Fenugreek (Trigonella foenum-graceum ) is commonly known as methi is an annual, self pollinating, legume crop, which though considered to have originated from the Mediterranean region. It is used in functional food, traditional food, nutraceuticals as well as antibacterial, anticancer, antiulcer, (Al Meshal et al., 1985) anthelmintic, hypocholesterolemic, (Singhal et al., 1982; Sharma, 1984; Sharma et al., 1996 and Valette et al., (1984) and antidiabetic agent (Shani et al., 1974). Fenugreek (methi) seeds have many therapeutical effects such as hypoglycaemic, (Sharma et al., 1990; Zia et al., 2001), anthelminthic, anti-inflammatory (Zargari, 1989; Mirhaydar, 1993). antimicrobial properties (Basch et al., 2003) gastroprotective (Suja et al., 2002), chemopreventive (Amin et al., 2005), antioxidant (Hettiarachchy et al., 1996; Kavirasan et al., 2007), laxative and appetite stimulation (Petit et al., 1993) attributes and are rich in protein, fat, total carbohydrates and minerals such as calcium, phosphorus, iron, zinc and magnesium. The plant and seeds are hot and dry, suppurative, aperient, diuretic, useful in dropsy, chronic cough, enlargement of the liver and the spleen. Keeping the nutritional and pharmacological properties in view, an experiment was conducted to evaluate the effect of dietary inclusion on the performance of broiler chickens.

\section{Materials and Methods}

A total of 120 day old broiler chicks were taken and randomly allocated into 4 groups with 3 replicates per group i.e. 10 chicks per replicate. Group $\mathrm{T}_{1}$ was used as a control and fed basal diet whereas chicks of group $T_{2}, T_{3}$, $\mathrm{T}_{4}$ were fed basal diet supplemented with $0.5 \%, 1.0 \%$ and $1.5 \%$ fenugreek leaf powder, respectively. Standard broiler diets for starter (0-3 weeks) and finisher (4-6 weeks) phases are provided to all the broiler chicks so as to meet the nutrient requirements as per BIS (1997). The feeds were analyzed for proximate principles as per standard method (AOAC, 1995). The broiler chicks were housed in a deep litter system and provided $a d$ libitum feed and water throughout the trial period. Body weight was measured at weekly interval during the entire experimental period. Feed consumption, feed conversion ratio, performance index and mortality rate were calculated. During the 30- 40 days of the experiment, a metabolic trial was conducted for three days on six of birds from each treatment group to know nutrient utilization. Data obtained by were analysed statistically following standard procedure (Snedecor and Cochran, 1994).

\section{Results and Discussion}

The cumulative growth performance of broilers in terms of average weight gain, feed intake, feed conversion ratio, and performance index as influenced by dietary inclusion of fenugreek leaf powder during starter phase (03 weeks) and finisher phase (4-6 weeks) is presented in Table 1. The weight gain showed significant $(\mathrm{P}<0.05)$ improvement due to 
dietary incorporation of fenugreek leaf powder. Maximum weight gain was recorded in broilers of treatment group $\mathrm{T}_{3}$ which was significantly $(\mathrm{P}<0.05)$ higher than $\mathrm{T}_{1}$. During the starter phase (0-21 days) there was significant differences in $\mathrm{T}_{3}$ group over the control group whereas other treatments were statistically similar. Highest weight gain and feed consumption was recorded by $\mathrm{T}_{3}$ group of broiler chicks fed diet supplemented with $1 \%$ fenugreek (methi) leaf powder. The results of present study corroborated with the findings of other researchers (Hernandez et al., 2004; Alloui et al., 2012) who observed that supplementation of fenugreek seed powder at various levels improved live body weight gain significantly. This might be due to the presence of the fatty acids, or due to stimulating effect on the digestive system of broilers.. Similarly other phytobiotics (herbs and spices) improved the growth performances as turmeric meal supplementation at the rate of $1.0 \mathrm{~g} / \mathrm{kg}$ improved growth performance of 42-d old broiler chickens (Kumari et al., 2007).

The cumulative performance of broiler finisher chicks in terms of weight gain, feed intake, FCR, and performance index during the finisher phase (22-42 weeks) as influenced by supplementation of different levels of fenugreek leaf powder in the diet is furnished in Table 2. There was significant difference in feed intake among the broilers of different treatment groups.

The feed intake of experimental birds (g/d) during finisher phase (4-6 wk) was higher in $\mathrm{T}_{3}$ group. Overall, the highest feed intake was also observed in $\mathrm{T}_{3}$ group supplementing with $1 \%$ fenugreek leaf powder. The highest feed intake in $\mathrm{T}_{3}$ group may also be attributed due to presence of neurine, biotin and trimethylamine in fenugreek, which acts as appetizer by stimulating the hunger centre present in the nervous system (Michael and
Kumawat 2003). During the finisher phase (46 wk) $T_{3}$ groups had significantly higher $(\mathrm{P}<0.05)$ body weight gain compared to control Steiner (2009) reported that fenugreek seed / leaf supplementation resulted in improvement in feed intake which could be attributed to the carbohydrates and their main component (galactomannan) which stimulated the appetizing and digestive process in animals. During finisher stage (4-6 wk), there was significant improvement in growth performance of broilers of $T_{3}$, in terms of weight gain, feed conversion ratio, feed intake and performance index.

The feed conversion ratio of broilers of treatment group $\mathrm{T}_{3}$ improved significantly $(\mathrm{P}<0.05)$ as compared to other treatment groups. These results agree with the finding of El-Gendi et al., (1994) which indicated that there was an improvement in feed conversion with feeding herbal products as feed additives that could be attributed to their effect on improving the digestibility of dietary protein in the small intestine. Tripathi et al.,(2013) reported that supplementation of hot red pepper in diets of quails increase the weight gain, reduced feed intake and improve feed conversion ratio similar to the findings of Solimon (2002) who reported that supplementation of hot red pepper decreased the feed intake and improved feed conversion. Gonzalez- Alvarado et al., (2007) supplemented the black cumin as phtyobiotic who reported that increased in nutrient digestibility are likely to be responsible for the improvement of body weight gain and feed conversion ratio as they increased the digesta retention time in the gizzard. Tripathi et al., (2013) reported that the supplementation of hot red pepper and black pepper as a phytobiotic in Japanese quail increases the body weight gain which may attributed to the to the better utilization of nutrients of the feed as red pepper has a protective function in the gastrointestinal mucosa. 
Table.1 Ingredient (\%) and nutrient composition (\%DM basis) of experimental broiler starter (0$3 \mathrm{wks})$ and broiler finisher (4-6 wks)

\begin{tabular}{|c|c|c|}
\hline Ingredients composition (\%) & Broiler Starter & Broiler Finisher \\
\hline Maize & 53.50 & 57.0 \\
\hline Soyabeal meal & 36.00 & 31.55 \\
\hline Rapeseed meal & 3.00 & 3.00 \\
\hline Rice polish & 3.00 & 2.6 \\
\hline Soyabean oil & 0.50 & 5.2 \\
\hline Limestone powder & 1.00 & 1.35 \\
\hline Dicalcium phosphate & 2.00 & 1.6 \\
\hline Common salt & 0.35 & 0.3 \\
\hline L-Lysine HCl & 0.10 & \\
\hline DL-methionine & 0.15 & 0.15 \\
\hline Trace mineral premix ${ }^{1}$ & 0.10 & 0.10 \\
\hline Vitamin- premix ${ }^{2}$ & 0.05 & 0.05 \\
\hline Choline chloride & 0.05 & 0.05 \\
\hline Toxin binder & 0.05 & 0.05 \\
\hline Coccidiostat & 0.05 & 0.05 \\
\hline \multicolumn{3}{|l|}{ Chemical composition (\% DM basis) } \\
\hline Dry matter & 90.71 & 90.80 \\
\hline Crude Protein & 22.93 & 20.16 \\
\hline Ether Extract & 4.42 & 4.38 \\
\hline Crude Fibre & 4.20 & 4.80 \\
\hline Total ash & 7.12 & 7.00 \\
\hline Calcium (\%) & 1.24 & 1.26 \\
\hline Total Phosphorus & 0.82 & 0.91 \\
\hline Available Phosphorus* & 0.51 & 0.45 \\
\hline Lysine $(\%)^{*}$ & 1.22 & 1.19 \\
\hline Methionine (\%)* & 0.49 & 0.44 \\
\hline Metabolisable energy (kcal/kg)* & 2794 & 2893 \\
\hline
\end{tabular}

*Calculated value

${ }^{1}$ Supplied (per kg diet): manganese, $90 \mathrm{mg}$; zinc, $72 \mathrm{mg}$; iron, $60 \mathrm{mg}$; copper, $10 \mathrm{mg}$ and iodine, $1.2 \mathrm{mg}$.

${ }^{2}$ Supplied (per kg diet): vitamin A,16500 IU; vitamin $\mathrm{D}_{3}$, $3200 \mathrm{ICU}$; vitamin E, $12 \mathrm{mg}$; vitamin $\mathrm{K}, 2 \mathrm{mg}$; vitamin $\mathrm{B}_{2}, 10 \mathrm{mg}$; vitamin $\mathrm{B}_{6}, 2.4 \mathrm{mg}$; vitamin $\mathrm{B}_{12}, 12 \mathrm{mg}$; niacin, $18 \mathrm{mg}$ and pantothenic acid, $12 \mathrm{mg}$. 
Table.2 Average cumulative growth performance of broiler chicks supplemented with fenugreek leaf powder

\begin{tabular}{|c|c|c|c|c|}
\hline \multirow[t]{4}{*}{ Parameters } & \multicolumn{4}{|c|}{ Treatments/ Groups } \\
\hline & $T_{1}$ & $\mathbf{T}_{2}$ & $\mathbf{T}_{3}$ & $T_{4}$ \\
\hline & $(0 \%)$ & $(0.5 \%)$ & $(1.0 \%)$ & $(1.5 \%)$ \\
\hline & Control & Fenugreek & Fenugreek & Fenugreek \\
\hline \multicolumn{5}{|c|}{ 0-21 days } \\
\hline Weight gain (g) & $636.40^{b} \pm 3.59$ & $673.58^{a} \pm 6.17$ & $685.2^{\mathrm{a}} \pm 5.46$ & $675.43^{\mathrm{a}} \pm 3.84$ \\
\hline Feed intake (g) & $962.98^{\mathrm{b}} \pm 4.38$ & $974.15^{b} \pm 7.39$ & $\begin{array}{c}1015.40^{\mathrm{a}} \pm 11.6 \\
9\end{array}$ & $982.21^{\mathrm{b}} \pm 11.47$ \\
\hline $\begin{array}{c}\text { Feed } \\
\text { conversion } \\
\text { ratio }\end{array}$ & $1.513^{\mathrm{a}} \pm 0.014$ & $1.446^{\mathrm{b}} \pm 0.024$ & $1.433^{\mathrm{b}} \pm 0.012$ & $1.503^{\mathrm{a}} \pm 0.008$ \\
\hline $\begin{array}{l}\text { Performance } \\
\text { index }\end{array}$ & $420.64^{c} \pm 6.33$ & $466.01^{\mathrm{ab}} \pm 12.15$ & $478.16^{\mathrm{a}} \pm 5.53$ & $449.29^{\mathrm{b}} \pm 0.35$ \\
\hline \multicolumn{5}{|c|}{ 22-42 days } \\
\hline Weight gain (g) & $1477.60^{b} \pm 8.24$ & $1489.7^{b} \pm 25.36$ & $1587.3^{\mathrm{a}} \pm 17.01$ & $1522.2^{\mathrm{b}} \pm 9.01$ \\
\hline Feed intake (g) & $3000.00^{b} \pm 32.46$ & $3022.50^{\mathrm{ab}} \pm 6.54$ & $3131.6^{\mathrm{a}} \pm 25.21$ & $3034.00^{\mathrm{ab}} \pm 50.37$ \\
\hline $\begin{array}{c}\text { Feed } \\
\text { conversion } \\
\text { ratio }\end{array}$ & $2.053^{\mathrm{a}} \pm 0.006$ & $1.990^{\mathrm{ab}} \pm 0.028$ & $1.973^{\mathrm{b}} \pm 0.008$ & $1.993^{\mathrm{ab}} \pm 0.021$ \\
\hline $\begin{array}{l}\text { Performance } \\
\text { index }\end{array}$ & $719.63^{\mathrm{a}} \pm 5.60$ & $754.10^{b} \pm 11.27$ & $804.28^{\mathrm{a}} \pm 11.73$ & $763.67^{b} \pm 4.43$ \\
\hline \multicolumn{5}{|l|}{$0-42$ days } \\
\hline Weight gain (g) & $2114.00^{c} \pm 9.68$ & $2187.2^{\mathrm{b}} \pm 7.64$ & $2272.5^{\mathrm{a}} \pm 14.69$ & $2193.80^{b} \pm 3.56$ \\
\hline Feed intake (g) & $4136.00^{b} \pm 36.72$ & $4319.8^{\mathrm{a}} \pm 8.33$ & $4333.8^{\mathrm{a}} \pm 40.11$ & $4175.4^{b} \pm 16.33$ \\
\hline $\begin{array}{l}\text { Feed } \\
\text { conversion } \\
\text { ratio }\end{array}$ & $2.010^{\mathrm{a}} \pm 0.036$ & $1.980^{\mathrm{a}} \pm 0.057$ & $1.820^{c} \pm 0.115$ & $1.903^{\mathrm{b}} \pm 0.008$ \\
\hline $\begin{array}{c}\text { Performance } \\
\text { index }\end{array}$ & $1052.50^{\mathrm{d}} \pm 22.58$ & $1104.70^{c} \pm 6.92$ & $1248.40^{\mathrm{a}} \pm 11.73$ & $1152.00^{b} \pm 6.67$ \\
\hline
\end{tabular}

a, b, c, d values bearing different superscripts in same row differ significantly $(\mathrm{P}<0.05)$.

Table.3 Average nutrient utilization (\%) in broilers chicks fed diets supplemented with Fenugreek leaf powder at $7^{\text {th }}$ week of age

\begin{tabular}{|c|c|c|c|c|}
\hline \multirow{2}{*}{ Parameter } & \multicolumn{4}{|c|}{ Treatments } \\
\cline { 2 - 5 } & $\mathbf{T}_{\mathbf{1}}$ & $\mathbf{T}_{\mathbf{2}}$ & $\mathbf{T}_{\mathbf{3}}$ & $\mathbf{T}_{\mathbf{4}}$ \\
\cline { 2 - 5 } & $(\mathbf{0 \%})$ & $(\mathbf{0 . 5 \%})$ & $(\mathbf{1 . 0 \%})$ & $(\mathbf{1 . 5 \% )}$ \\
& Control & Fenugreek & Fenugreek & Fenugreek \\
\hline Dry matter & $71.88^{\mathrm{b}} \pm 1.58$ & $72.39^{\mathrm{b}} \pm 1.61$ & $76.94^{\mathrm{a}} \pm 0.65$ & $74.38^{\mathrm{ab}} \pm 1.01$ \\
\hline Crude Protein & $67.55^{\mathrm{c}} \pm 1.22$ & $74.73^{\mathrm{ab}} \pm 1.09$ & $77.49^{\mathrm{a}} \pm 0.69$ & $71.75^{\mathrm{b}} \pm 0.85$ \\
\hline Ether Extract & $74.92^{\mathrm{b}} \pm 0.84$ & $79.51^{\mathrm{a}} \pm 1.10$ & $80.54^{\mathrm{a}} \pm 0.06$ & $75.56^{\mathrm{b}} \pm 0.10$ \\
\hline
\end{tabular}

$\mathrm{a}, \mathrm{b}, \mathrm{c}, \mathrm{d}$ values bearing different superscripts in same row differ significantly $(\mathrm{P}<0.05)$. 
The black pepper improved the weight gain which might be attributed to the fact that it helps in digestion and absorption and thus, enhances growth rate, feed efficiency and prevent intestinal infections (Mohan et al., 1996)

Data pertaining to the average nutrient utilization in broilers during finisher phase of different treatments groups are presented in Table 3.

The nutrient utilization such as dry matter, crude protein and ether extract in broilers during the metabolism trial revealed significant $(\mathrm{P}<0.05)$ improvement in broilers of treatment $\mathrm{T}_{3}$ group as compared to other treatment groups. Samarasinghe et al., (2003) reported improved protein utilization due to turmeric supplementation in broilers.

The present findings are in agreement to that of Issa and Omar (2012) who reported improved digestibility of dry matter, crude protein and ether extract by feeding garlic powder as feed additive in broilers diet. Rajput et al., 2013) revealed that ether extract utilization also improved significantly due to dietary supplementation of curcumin as a phytobiotic in broiler chicks.

The improvement of total tract digestibility in broilers fed different levels of garlic powder as a phytobiotic was probably due to herbal effects in increasing the microbial population especially the number of bacteria such as $E$. coli, Clostridium spp. and Enterococci (Issa and Omar, 2012).

In the view of the aforesaid findings, It can be concluded that dietary incorporation of fenugreek leaf powder at the rate of $10 \mathrm{~g} / \mathrm{kg}$ of feed ( $1 \%$ in basal diet) of broiler chicks improved growth performance, feed conversion ratio and utilization of nutrients without any harmful effects.

\section{References}

Al Meshal, I.A., Parmar, N.S., Tariq, M. and Aqeel, A.M., 1985.Gastric antiulcer activity in rats of Trigonellafoenumgraecum (Hu-Lu-Pa).Fitoterapia 56: 232-235.

Alloui, N., Ben, S., Alloui, M.N. and Ibrir, F. 2012. Utilization of fenugreek (Trigonellafoenum-graecum) as growth promoter for broiler chickens. J. World's Poult. Res. 2, 25-27.

Amin, A., Alkaabi, A., Al-Falasi, S. and Daoud, S. A. 2005.Chemopreventive activities of Trigonellafoenumgraecum (Fenugreek) against breast cancer. Cell Biology International, 29, 687- 694

Azouz HMM 2001 Effect of hot pepper and fenugreek seeds supplementation on broiler

Basch, E., C. Ulbricht, G. Kuo, P. Szapary and M. Smith, 2003.Therapeutic applications of fenugreek. diets. Ph.D. Thesis, Poultry Nutrition Dept. Faculty of Agriculture, Cairo University.Alt. Med. Rev., 8: 20-27.

El-Gendi, G.M., F.A. Ismail and S.M. ElAggoury, 1994.Effect of Cocci-Nel and Lomoton dietary supplementation as herbal growth promoters on productive performance of broiler. Ann. Agric. Sci.Moshtohor, 32: 15111528.

Fazli, F. R., and Hardman, R. 1968. The spice, fenugreek (Trigonellafoenum graceum L.): its commercial varieties of seed as a source of diosgenin. Tropical Sci. 10: 66-78.

Fazli, F.R.Y., and Hardman, R., 1971. Isolation and characterization of steriods and other constituent from Trigonellafoenum-graecum.

Phytochemistry 10, 2497- 2503.

Gonzalez-Alvarado, J.M., Jiménez-Moreno, E., Lázaro, R., Mateos, G.G., 
2007.Effect of typeof cereal, heat processing of the cereal, and inclusion of fiber in the diet on productive performance and digestive traits of broilers. Poultry Sci. 86:1705-1715.

Hernandez, F., Mardrid, J., Garcia, V., Orengo, J. and Megias, M.D. (2004). Influence of two plant extracts on broiler performance, digestibility, and digestive organ size. Poult. Sci. 83: 169-174.

Hettiarachchy, N. S., Glenn, K. C., Gnanasambandam, R., and Johnson, M. G. 1996. Natural antioxidant extract from fenugreek (Trigonellafoenum graceum) for ground beef patties. Journal of Food Science, 61, 516-519

Issa, K. J. and Omar, J. M. 2012. Effect of garlic powder on performance and lipid profile of broilers. Open Journal of Animal Sciences. 2 (2): 62-68.

Kavirasan, S., Naik, G. H., Gangabhagirathi, R., Anuradha, C. V., and Priyadarsini, $\mathrm{K}$. I. 2007. In vitro studies on antiradical and antioxidant activities of fenugreek (Trigonellafoenumgraceum) seeds. Food Chemistry, 103: 31-37

Kumari, P., Gupta, M. K., Ranjan, R., Singh, K. K. and Yadava, R. 2007. Cucurma longa as feed additive in broiler birds and its patho-physiological effects. Indian Journal of Experimental Biology.45: 272-77.

Lee, K.W., Evarts, H, and Beynen, V. 2004. Essential oils in broiler nutrition. Int.J. Poultry Sci., 3: 738-52.

Michael, D. and D. Kumawat, 2003.Legend and archeology of fenugreek, constitutions and modern applications of fenugreek seeds. InternationalSymp., USA.,pp: 41-42.

Mirhaydar, H., 1993. Plant Information, 1.NashreFarhangIslami Press, Iran, p. 145.
Mohan, B., Kadirvel, R., Natarajan, A. and Bhaskaran. M. 1996. Effect of probiotics supplementation on growth, nitrogen utilization and serum cholesterol in broilers. Brit. Poult. Sci. 37: 395-401.

Murray, R.K., Granner, D.K. Mayes P.A. and Rodwell, V.W. 1991. The Text Book of Harpers Biochemistry. 22nd Edn., Applecton and large. Norwalk, Connecticut/Loss Altos, California.

Petit, P., Sauvaire, Y., Ponsin, G., Manteghetti, M., Fave, A. and Ribes, G. 1993. Effect of a fenugreek seed extraction on feeding behavior in the rat: metabolic-endocrine correlates. Pharmacology, Biochemistry and Behavior, 45: 369-374.

Rajput, N., Muhammad, N., Yaan, R., Zhong, X. and Wang, T. 2013.Effect of dietary supplementation of curcumin on growth performance, intestinal morphology and nutrients utilization of broiler chicks. Journal of Poultry Science.50: 44-52.

Samarasinghe, K., Wenk Silva, K. F. S. T. And Gunasekera, J. M. D. M. 2003. Turmeric (Curcuma longa) root powder and mannanoligosaccharides as alternatives to antibiotics in broiler chicken diets. Asian-Australian Journal of Animal Sciences.16 (10): 1495-1500.

Shani, J., Gold Schmied, A., Ahronson, Z. and Sulman, F.G., 1974. Hypoglycaemic effect of Trigonellafoenum-graecum and Lupinustermis (Leguminosae) seeds and their major alkaloids in alloxan diabetic and normal rats. Arch International Pharmacodynamics Therapy 210: 27-36.

Sharma, R.D., 1984. Hypocholesterolaemic activity of Fenugreek ( $T$. foenumgraecum). An experimental study in rats. Nutrition Reports International 30: 221-231. 
Sharma, R.D., Sarkar, A. and Hazra, D.K., 1996. Hypolipidaemic effect of Fenugreek seeds: a chronic study in non-insulin dependent diabetic patient. Phytotherpay Research 10: 332-334.

Singhal, P. C., Gupta, R. K. and Joshi, L. D. 1982. Hypocholesterolemic effect of Trigonella foenum-graecum. Current Science 51: 136-137.

Snedecor, G.W. and Cochran, W.G. 1994. Statistical methods. 9th edn. The lowa State University Press, Ames, Iowa, USA.

Solimon A. Z. 2002 The bioefficacy of hot pepper in practical layer diets varying in their energy diets and energy content. Egypt Poult.Sci.22: 931-951.

Steiner, T. 2009. Phytogenics in Animal Nutrition. Natural Concepts to Optimize Gut Health and Performance.
Nottingham University Press.

Suja Pandian, R., Anuradha, V. V. and Viswanathan, $\quad$ P. 2002. Gastroprotective effect of fenugreek seeds (Trigonellafoenum-graecum) on experimental gastric ulcer in rats.Journal of Ethno pharmacology, 81, 393-397.

Tripathi, D., Kumar, A., Mondal, B.C., Rahal, A. and Palod, J. 2013. Effect of ajwain, hot pepper and black pepper on performance of Japanese quails. Indian J. Anim. Nutr. 30(4): 431-433.

Valette, G., Sauvaire, Y., Baccou, J. C. and Ribes, C. 1984. Hypocholesterolemic effect of fenugreek seeds in dogs. Atherosclerosis 50: 105-1 11.

Zargari, A. 1989. Medicinal Plants, 1. Tehran University Press, Iran, pp. 637-639.

\section{How to cite this article:}

Nandita, B. C. Mondal and Manju Lata. 2021. Effect of Dietary Incorporation of Dried Fenugreek (Trigonellafoenum-graceum) Leaf Powder on Growth Performance and Nutrient utilization in Commercial Broiler Chicken. Int.J.Curr.Microbiol.App.Sci. 10(02): 1254-1261. doi: https://doi.org/10.20546/ijcmas.2021.1002.148 